ASCERTAINMENT BIAS A systematic distortion in measuring the truefrequency of a phenomenon, such as a trait or a disease, owing to the way in which the data are obtained.

\title{
CLASSICAL TWIN STUDIES AND BEYOND
}

\section{Dorret Boomsma*, Andreas Busjahn ${ }^{\ddagger}$ and Leena Peltonen ${ }^{\S}$}

Twin studies have been a valuable source of information about the genetic basis of complex traits. To maximize the potential of twin studies, large, worldwide registers of data on twins and their relatives have been established. Here, we provide an overview of the current resources for twin research. These can be used to obtain insights into the genetic epidemiology of complex traits and diseases, to study the interaction of genotype with sex, age and lifestyle factors, and to study the causes of co-morbidity between traits and diseases. Because of their design, these registers offer unique opportunities for selected sampling for quantitative trait loci linkage and association studies.

Recent advances in genetics, such as the completion of the human genome sequence, an increased understanding of sequence variants, the availability of low-cost genome-wide tools to monitor these variants and the development of powerful multivariatestatistical tools, have opened new avenues of investigation in human genetics. There is a danger, however, that the usefulness of these toolsislimited when applied to human complex traits. ASCERTAINM ENT BIAS, problems with phenotypic assessment, lack of follow-up of the phenotypes over time and environmental noise that can arise, for example, from developmental variation, might all contribute to making the genes that underliecomplex, multifactorial traits and diseases in humans difficult to identify. During the past decade, considerable effort has been devoted to whole-genomescreens to detect QUANTITATIVE TRAIT LOCI (QTL) for complex traits and diseases. The success of linkage studies to map genes of unknown function, and LINKAGE-DISEQUILIBRIUM studies that are aimed at establishing the association between a particular genetic polymorphism and a disease, are considered by some researchers to have been limited (for example, see REFS 1,2). But others, such as Korstanje and Paigen ${ }^{3}$, find this pessimistic view premature. Instead, they offer a more optimistic view by summarizing the acceleration in geneidentification from mammalian QTL in the past ten years - for example, Crohn disease in humans, blood pressure in rats and diabetes in mice. Although animal research might provide essential information, it cannot encompass the complex interplay of genes with the human environment. For complex human traits, there is an increasing recognition of theneed to understand population genetics and the biometrical properties of human traits, so that phenotypes can bedefined in a way that maximizes the chances of successful gene mapping 4 . In this review, wediscuss how twin studies can help in this endeavour.

Weaim to draw the attention of the reader to the enormous potential for research on the genetics of complex traits that lies in the established twin registers. Some of them have existed for decades and have carefully collected LONGITUDINAL DATA on behavioural traits, diseases and environmental risk factors in large samples of twins and their families. By facilitating comparisons between monozygotic (M Z) and dizygotic (DZ) twins, twin registers represent some of the best resources for evaluating the importance of genetic variation in susceptibility to disease. They are also an excellent resource for studying the significance of the GENOTYPE $\times$ ENVIRONMENT INTERACTION (for example, lifestyle; seethe section on 'Improvements in analysis' for further discussion) and of the contribution of specific polymorphisms to the total genetic variance. Nevertheless, these facts, and the existence of twin registers, remain to be appreciated fully by the wider community of genetic researchers. 
QUANTITATIVE TRAIT LOCUS (QTL). Genetic locus or chromosomal region that contributes to the variability in complex quantitativetraits, as identified by statistical analysis. Quantitativetraits aretypically affected by several genes and the environment.

LINKAGE DISEQUILIBRIUM (LD). The condition in which the frequency of a particular haplotype for two loci is significantly greater than that expected from the product of the observed allelic frequencies at each locus.

LONGITUDINAL STUDY A study in which repeated measurements are taken from the same subjects at different timepoints.

GENOTYPE $\times$ ENVIRONMENT INTERACTION

$(G \times E)$. Theinfluence of specific combinations of genetic and environmental factors on a trait that goes beyond the additive action of thesefactors. It refers to genes that control sensitivity to theenvironment, or the environment that controls gene expression.

MULTIVARIATE ANALYSIS Thesimultaneousinclusion of two or more (dependent) variablesin oneanalysis, for example, in estimating the genetic correlation of birth weight with blood pressure.

COVARIATE

In a multivariate analysis, a variablewith known effects that is used to test the effect of the main variables that are independent of those known effects. Theinclusion of agein studies of age dependent traits is a simpleexample.

HERITABILITY

The proportion of the total phenotypic variation in a given characteristic that can be attributed to additivegenetic effects. In the broad sense, heritability involves all additive and non-additive genetic variance, whereas in the narrow sense, it involves only additive genetic variance

CONCORDANCE

The occurrence of the sametrait in both members of a pair of twins. Concordance might occur for diseases as well as for behaviours, such as smoking.

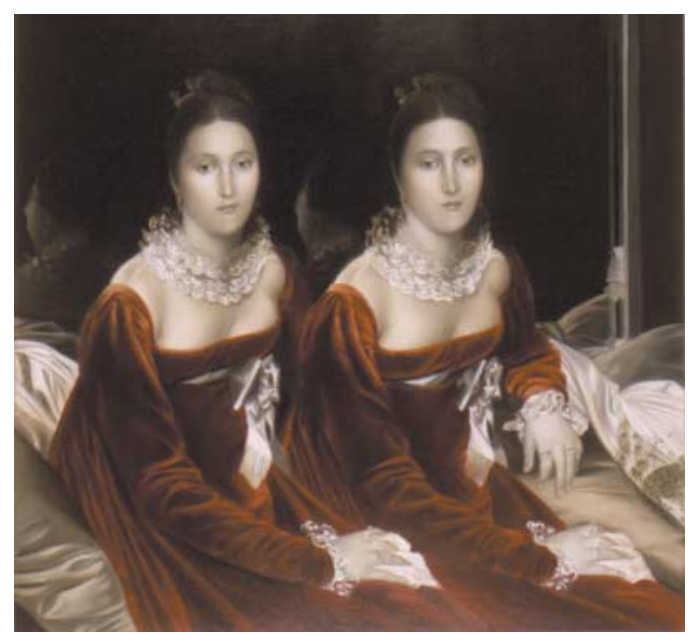

Figure 1 | Velvet twins. Oil painting on linen $(145 \mathrm{~cm} \times 135 \mathrm{~cm})$ by Mary Waters (1997/1998). From a private collection, courtesy of Flatland Off the Record (publishers), Utrecht, The Netherlands.

To disentangleand to quantify the contributionsthat genes, the shared environment, the individual-specific environment and their interactions maketo human complex traits, wened datafrom relatives who aregenetically related, but who grow up in unrelated environments (the so-called 'twin adoption design'), or relatives who grow up in similar environments but are of differing genetic relatedness (theso-called 'twin design'). If theexposureto environmental risk factors can be assessed, thesedesigns also make it possible to quantify the effect that thegenotype $\times$ environment interaction has on shaping a particular trait. Recent advances in statistical modelling allow simultaneous analysis of many variables in relatives such as M Z and DZ twins. Theseadvances also make it possible to carry out new types of analysis - such as the MULTIVARIATEANALYSIS of causes of co-morbidity between disorders, the analysis of the development of childhood psychopathology over time, theinclusion of COVARIATES in linkageanalyses, and theestimation of HERITABILITY and linkagethat areconditional on theexposure to environmental risk factors. All theseimprovements in data analysis and the possibilities of new types of analysis have, in turn, led to the establishment of large registers of twins that no longer focus on the assessment of a single phenotype, but collect a widerange of traits and environmental factorsin twins, as well as in their family members.

Here, we focus on the use of data from twins and their families in epidemiological and molecular-genetic studies. Wedraw attention to a large resourcefor such studies and providean overview of the most important features of twin registers worldwide. But first, webriefly introducethe classical twin designs and contrast them with some of their recent extensions.

\section{Types of twin study design}

Twins haveal ways captured our curiosity, researchers and artists alike (FIG. 1), and there havebeen proposals to use them as a'natural experiment' in empirical studies as early as 415 AD (REF. 5). Galton's classic paper on twins, published in thenineteenth century ${ }^{6}$ is often cited as the first on the classical twin method, although it is uncertain if Galton knew of the distinction between $M Z$ and $D Z$ twins ${ }^{7,8}$. The systematic analysis of similarity between $M Z$ and DZ twins was introduced by Siemens, a dermatologist, who formulated the twin rule of pathology: any heritabledisease will be more CONCORDANT in identical twinsthan in non-identical twins, and concordancewill be even lower in non-siblings ${ }^{9}$. When studying skin moles, Siemens came up with theclever idea of combining correlation analysis with twin data: he correlated molecounts in one twin with molecounts in theother twin, and compared this correlation in MZ and DZ pairs of twins. The correlation for molecount in $M Z$ twins, who shareall, or nearly all, of their genetic material was 0.4. In DZ twins, who aregenetically $50 \%$ identical on average, the correlation was only 0.2 . The results indicated theimportance of genetic factors in variation in mole count - the greater genetic resemblance in M Z twins is associated with their greater resemblancefor the phenotypeunder study.

Classical twin studies. As exemplified above, the classical twin study compares phenotypic resemblances of $M Z$ and $D Z$ twins. $M Z$ twins derivefrom a single fertilized egg and therefore inherit identical genetic material. Comparing the resemblance of $\mathrm{MZ}$ twins for a trait or disease with the resemblance of $D Z$ twins offers the first estimate of the extent to which genetic variation determines phenotypic variation of that trait. If $\mathrm{M} \mathrm{Z}$ twins resemble each other morethan do DZ twins, then the heritability $\left(\mathrm{h}^{2}\right)$ of thephenotype can be estimated from twice the difference between $M Z$ and $D Z$ correlations. For example, typical $M Z$ and $D Z$ correlations for depression areabout 0.4 and 0.2 (REF. 10), and therefore heritability is estimated at $\sim 40 \%$. A different pattern of correlations is usually observed for lifestyle factors, indicating the importance of the shared family environment. For taking up smoking during adolescence, typical $\mathrm{MZ}$ and DZ correlations are 0.9 and 0.7 , respectively (REF. 11), leading to a heritability estimate of $40 \%$, but also indicating theimportance of a shared environment. The proportion of the variance that is dueto a shared environment is the difference between thetotal twin correlation and the part that is explained by heritability. That is, $r_{M Z}-h^{2}$ in $M Z$ or $r_{D z}-h^{2} / 2$ in DZ twins, where $r_{M Z}$ is the correlation between $M Z$ twins and $r_{D Z}$ is the correlation between $D Z$ twins. For the trait of taking up smoking, this estimate is $~ 50 \%(0.9-0.4$ in MZ or $0.7-0.2$ in DZ twins). The application of this type of analysis has led to substantial changes in the way we think about the determinants of health and disease, and the causes of individual differences in normal and abnormal behaviour. During the past decade, a shift has taken place from strict environmental explanations to a more balanced view that recognizes the importance of genes $^{12}$ - for example, in autism and in attentiondeficit hyperactivity disorder (ADHD) in children ${ }^{13,14}$, or in the development of dependence on alcohol and other drugs ${ }^{15,16}$ (FIG. 2). 


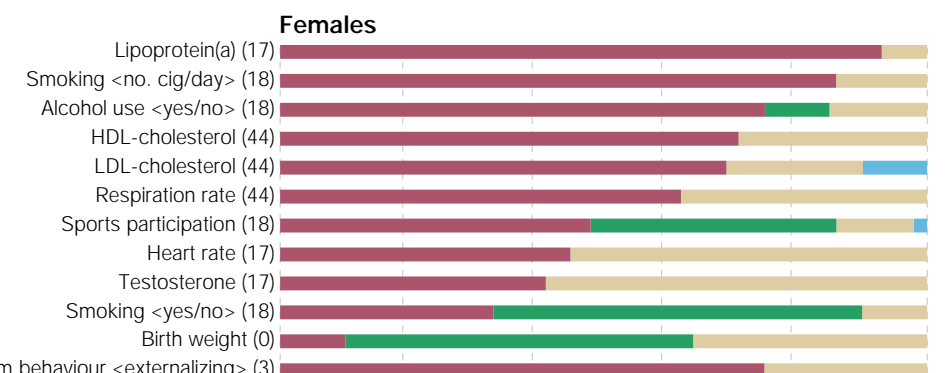

roblem behaviour <internalizing > (3)

Thrill and adventure seeking (18)

Disinhibition (18)

Neuroticism (18)
Experience seeking (18)

Anxiety (18)

Depression (18)

Boredom susceptibility (18)

Cognitive failures (17)

Somatic complaints (18)

Religion (18)

Intelligence (5)

Intelligence (7)

Intelligence (10)

Intelligence (16)

Intelligence (18)

Intelligence (27)

\begin{abstract}
20
\end{abstract}
40

60

80

100

Males
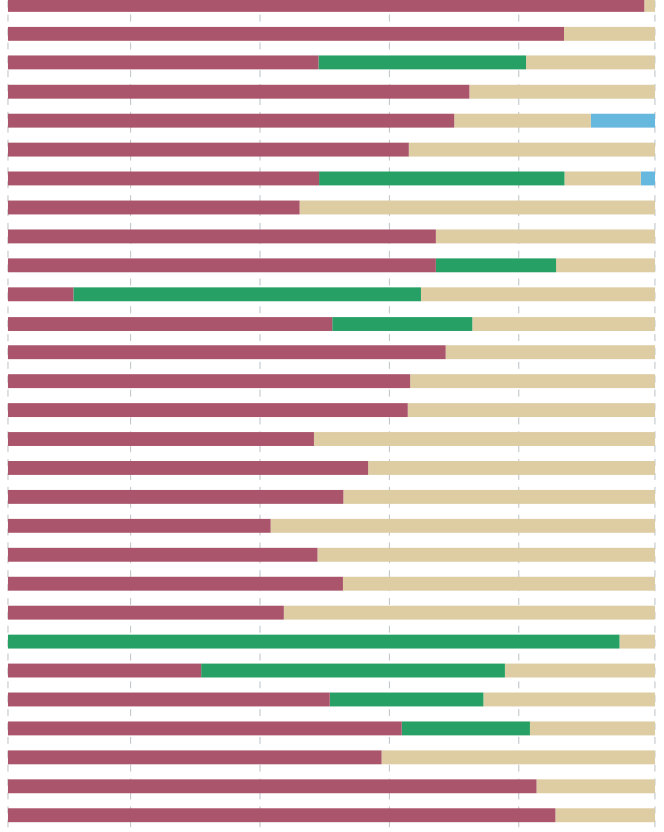

Percentage of variance

Figure 2 | Examples of results from classical twin analysis. Percentage of variances explained by genetic factors (purple), by shared environmental factors (green), by unique environmental influences (beige) and by differences in age (blue). The phenotypes were assessed in Dutch female and male twins (and in some cases also in their parents and siblings). The number in the brackets gives the modal age of the sample in years. Phenotypes include cardiovascular risk factors, and personality and cognitive traits. The heritability for a behavioural as well as cardiovascular risk factor, such as the number of cigarettes smoked per day, is nearly as high as for lipoprotein(a) levels. For personality traits and indices of psychopathology, heritability is $\sim 50 \%$, with a higher estimate for internalizing and externalizing problems in young children. Heritability of intelligence is age dependent and increases rapidly between 5 and 18 years of age. There are few differences in heritability between females and males. HDL, high-density lipoprotein; LDL, lowdensity lipoprotein. Modified with permission from REF. 23 @ (1999) Australian Academic Press.

ANALYSISOF VARIANCE

(ANOVA). A statistical method to test thenull hypothesis that themean values of two or more groups are equal. The variance around themeansin groups is compared with the variance of thegroup means. In genetic applications, the variance between families is compared with the variance within families. A significant F-ratio implies that variance between families islarger than within families.

INTRA-CLASS CORRELATION A statistical measurefor the strength and direction of resemblance between two variables (or two family members). It can vary between

-1 and +1 . Intra-class correlation refers to the correlation in defined subgroups - for example, in monozygotic or dizygotic pairs - and can be derived from AN OVA as $\mathrm{t}=(\mathrm{F}-1) /(\mathrm{F}+1)$.
Improvementsin analysis. The quantitative traits that have been assessed in M Z and DZ twins havetraditionally been analysed using ANALYSIS OF VARIANCE and INTRA-CLASS CORRELATIONS to summarize twin resemblance (for example, see REF. 17). This approach, however, cannot accommodate the effect of gender on variances and covariances of twins of opposite sexes. STRUCTURAL EQUATION M ODELLING (SEM), also known as covariance modelling, is a moregeneral alternative approach, in which genotypic and environmental effects are modelled as the contribution of unmeasured (latent) variables to the potentially multivariate phenotypic differences between individuals ${ }^{18}$. The latent factors repre sent the effects of many unidentified influences. For a genetic factor, these effects are due to a potentially large, but unknown, number of POLYGENES. The contributions of the latent variables are estimated as REGRESSION COEFFICIENTS in the LINEAR REGRESSION of the observed variables on thelatent variables. Several widely available software programs, such as LISREL ${ }^{19}$ or $M \mathrm{X}^{20}$ allow the estimation of parameters by using NORM AL THEORY MAXIMUM LIKELIHOOD and WEIGHTED LEAST SQUARES. A useful estimator in the $M \times$ program is the raw data likelihood estimator, which handles data from selected samples and from studies in which part of the sample might have missing data. The latter often arises in longitudinal studies. SEM can accommodatetheanalysis of gender differences in heritability estimatesthrough thesimultaneous analysis of data from male and female $M Z$ and DZ twins. It is possible to test whether the samegenes are expressed in males and females by including DZ twins of opposite sexes. If the resemblance between twins of opposite sexes is less than expected on the basis of the heritability in males and females, then this indicates that different genes might influence the same trait in the two sexes. Similarly, heritability that is conditional on environmental exposure can indicate the presence of a genotype $\times$ environment interaction ${ }^{21}$. This interaction can be detected by including environmental measurements on the basis of which the twin samplecan be stratified. For example, H eath et al. ${ }^{22}$ found that heritability for depression in married women was lower than in unmarried women.

Evidence for the effect of the genotype $x$ environment interaction on personality comes from a study in Dutch adolescent twins, in which it was shown that a religious upbringing greatly reduces the influence of genetic factors on DISINHIBITION, a trait that closely resembles 'novelty seeking' and that is associated with substance useand abuse ${ }^{23}$. 
STRUCTURAL EQUATION MODELLING

(SEM). Also known as covariancemodelling. A method that estimates regression coefficients ('parameters') between latent (unobserved) and observed variables. These estimates minimizethe difference between the covariancestructure of the observed data and that predicted by themodel. Alternativemodels (such asfamily resemblance being due to shared genes versus shared environment) can be compared by how well they fit the data and by thenumber of parameters estimated.

POLYGENES

A group of genes that influencea complex trait. In contrast to monogenic traits, most traits and diseases areinfluenced by several genes, only a sum of which is sufficient to cause the effect.
Beyond the dassical designs. TABLE 1 summarizes the possibilities for research that go beyond the classical twin design. Extending the $M Z-D Z$ design to includethe testing of parents, siblings, spouses and offspring of both M Z and DZ twins, offers the opportunity to assess the presence of cultural transmission, genotype $\times$ environment covariance, non-random mating, and social interactions within and between generations ${ }^{24}$. Simpler versions of the fuller, extended twin studies - such as a study of youngadult twins, their middle-aged parents and a second group of middle aged twins (that is, twins of the sameage as the parents of the first group of pairs of twins) makes it possibleto assess the effect of age differences on heritability and to assess differential geneexpression asa function of age. Usingthis design, which can beconsidered a shortcut for a true longitudinal study, Snieder et al. ${ }^{25}$ obtained evidence that partially different genes influence lipid levels in plasma at different ages. This might beimportant information for gene-finding studies, as theremight only be alimited timeperiod during which genes that vary over the course of an individual'slifecan be detected. Other extended twin studies look at the

\begin{tabular}{|c|c|}
\hline Types of twin study & Application \\
\hline $\begin{array}{l}\text { Classical MZ-DZ } \\
\text { comparison }\end{array}$ & $\begin{array}{l}\text { These studies estimate the contributions of genetic and } \\
\text { environmental effects to phenotypic variance, and test, } \\
\text { for example, for age, cohort and sex differences in gene } \\
\text { expression }\end{array}$ \\
\hline $\begin{array}{l}\text { Multivariate analyses: } \\
\text { simultaneous analysis of } \\
\text { correlated traits }\end{array}$ & $\begin{array}{l}\text { This type of analysis involves: } \\
\text { - direction of phenotypic causality } \\
\text { - causes of co-morbidity of two or more traits: } \\
\text { multivariate modelling of environmental and genetic } \\
\text { correlations between traits } \\
\text { - multivariate modelling to obtain genotypic (or } \\
\text { environmental) values for individuals } \\
\text { - analysis of longitudinal data to study causes of } \\
\text { phenotypic stability and tracking over time } \\
\text { - testing of } G \times E \text { using measured environmental indices }\end{array}$ \\
\hline Co-twin control study & $\begin{array}{l}\text { Case-control studies of MZ twins who are perfectly } \\
\text { matched for genes and family background; such studies } \\
\text { can also be used to study gene expression in } \\
\text { discordant twins }\end{array}$ \\
\hline $\begin{array}{l}\text { Extended twin study: } \\
\text { studies of twins and } \\
\text { their families }\end{array}$ & $\begin{array}{l}\text { - Parents of twins can be included to study cultural } \\
\text { transmission and } G \times E \text { covariance } \\
\text { - Parents of twins can be studied in a quasi-longitudinal } \\
\text { design to determine genetic and environmental stability } \\
\text { - Assortative mating can be studied if spouses of twins } \\
\text { are included; social interactions and special twin } \\
\text { effects, such as prenatal hormone transition, the } \\
\text { 'private language' of twins and shared prenatal } \\
\text { environment, can be studied if siblings of twins } \\
\text { are included } \\
\text { - Maternal effects, } G \times E \text { correlation and imprinting } \\
\text { can be studied if offspring of MZ twins are included }\end{array}$ \\
\hline $\begin{array}{l}\text { Genotyping at candidate } \\
\text { loci }\end{array}$ & $\begin{array}{l}\text { These studies include: } \\
\text { - genotyping of MZ twins to detect variability genes } \\
\text { and to estimate penetrance } \\
\text { - genotyping of DZ twins to estimate associations } \\
\text { within and between families }\end{array}$ \\
\hline Genotyping at marker loci & $\begin{array}{l}\text { These studies include: } \\
\text { - genotyping of DZ twins (and parents) to detect } \\
\text { linkage with QTL } \\
\text { - selecting informative families from large twin registers } \\
\text { to find QTL of small effect }\end{array}$ \\
\hline
\end{tabular}

$\mathrm{DZ}$, dizygotic; $\mathrm{G} \times \mathrm{E}$, genotype $\times$ environment interaction; $\mathrm{MZ}$, monozygotic; $\mathrm{QTL}$, quantitative trait loci. offspring of $M Z$ twins who are genetically half-sibs but socially cousins ${ }^{26}$. The M Z-offspring design also allows for the testing of maternal effectsand imprinting by comparing the offspring of maleand femaleM Z pairs.

Multivariatedesigns. By generalizing theunivariatetwin study to multivariate designs, in which morethan one phenotype per person is analysed, the causes of association and co-morbidity between traits can be investigated. Multivariatetwin studies make it possibleto ask questions such as: Does variation in exercise behaviour cause variation in depression, or do the traits cluster because they areinfluenced by a common set of genes? Or, to giveanother example, do symptoms of anxiety and those of depression cluster because one disorder increases the risk for the other, or is there a common genetic vulnerability?? ${ }^{27,28}$ The answers to these questions liein the cross-twin, cross-trait correlations in MZ versus DZ pairs of twins, such as the correlation of anxiety in one twin with depression in theother twin. Using this design, Nealeand Kendler ${ }^{28}$ and Roy et al..$^{29}$ found that co-morbidity between major depression (MD) and generalized anxiety disorder (GAD) is not dueto chance or to a third independent disorder, but is probably caused by correlated susceptibilities to the disorders. Themodel that best explained the association of MD and GAD included a strong genetic correlation (of one) between $M D$ and $G A D$, and a weak correlation with theindividual-specific environment. GAD and M D therefore share genetic factors, but their environmental determinants aremostly distinct.

Co-morbidity, the occurrence of two or moredisorders together, is often seen as a problem in moleculargenetic psychiatric studies. To overcome this problem, valid and objective diagnostic categories need to be established. It is important to remember, however, that a diagnostic label can bevalid, without necessarily being biologically meaningful ${ }^{30}$. ADHD is a good example of the importance of diagnostic categories. In clinical settings, $\sim 50 \%$ of children who meet the criteria for ADHD also meet the criteria for oppositional defiant disorder (ODD) and conduct disorder (CD), and another $20-25 \%$ of children with ADHD also meet the criteria for an anxiety disorder ${ }^{31}$. Strategies for linkage studies of ADHD could focus on 'pure' cases (for example, children who haveADHD without any co-morbid problems of ODD or anxiety) or on distinguishing in the patient sample between ADHD cases with different co-morbid conditions. Instead of agreeing on a particular scheme before carrying out a linkagestudy, it might bemore powerful to analyse the causes of co-morbidity in a multivariatetwin design and to establish the extent to which the phenotypes that cluster sharea common genetic basis. Twin registers can be extremely helpful in this respect by coming up with reliable phenotypes that can be useful in molecular-genetic studies. Again, twin studies of ADHD are an example. Todd et al. ${ }^{32}$ found that different ADHD subtypes are influenced by different genetic factors. M oreover, the genetically distinct severe subtype also accounted for most of the comorbidity in the sample ${ }^{33}$. It therefore seems that 
REGRESSION COEFFICIENTS/ LINEAR REGRESSION

Linear regression is a statistical method to test and to describe thelinear relationship between two or more variables. The regression coefficient describes the angle of theregression line and reflects the amount of variance of the dependent variablethat is explained by variation of theindependent variable.

NORM AL THEORY M AXIMUM LIKELIHOOD

(ML). A statistical method that works by varying the estimates for parameters of a model, so that thelikelihood of the observed data points is maximized. Under normal theory, thelikelihood corresponds to the height of the normal curve (one variable) and to the height of themultivariate normal probability density

function for two or more variables.

WEIGHTED LEAST SQUARES (WLS). An alternativemethod for estimating parameters during model fitting. The square of the difference between the observed statistic (for example, mean or covariance) and the statistic that is predicted by the theoretical model is weighted and minimized. Weights are usually chosen to correspond to the accuracy of the observed statistics.

DISINHIBITION

A sub-scale of the psychologica trait 'sensation seeking' including items that describe experiences or attitudes that relateto sensation seeking through other exciting people, disinhibited or 'wild' parties, social drinking and sexual variety.

ENDOPHENOTYPES/ INTERM EDIATE PHENOTYPES The physiological traits that are related to a disease trait; for example, for hypertension this could includeblood pressure, angiotensin levels or salt sensitivity.

PENETRANCE

The proportion of affected individuals among the carriers of a particular genotype. If all individuals with a disease genotype show the disease phenotype, then the diseaseis said to becompletely penetrant separate genetic vulnerabilities account for ADHD alone and for ADHD with co-morbid conditions. Pending replication, these results provide a clear indication that linkagestudies without phenotypic subtyping would bestruggling to deal with different genotypes that underlie a seemingly similar phenotype.

Multivariate analyses are also needed for the simultaneous modelling of phenotypes (such as depression) and ENDOPHENOTYPES Or INTERM EDIATE PHENOTYPES (sUCh aS neuroticism or cortisol levels) to determinetheir common genetic aetiology. The power to detect linkage will only beincreased through the use of endophenotypes if their association is due to pleiotropic genetic effects ${ }^{34}$.

Case-control studies. Twins are also useful in casecontrol studies. M Z twins offer the possibility of carrying out theideal case-control study, as they are perfectly matched for genotypeand family background. M artin et al. ${ }^{35}$ studied vitamin $\mathrm{C}$ administration in one twin and a placebo in the other twin, and found that, contrary to popular belief, therewas no effect of vitamin C on the common cold. Studies of the effects of fetal and infant growth on later health (theBarker hypothesis; for example, see REF. 36) in twins have looked at the differences in birth weight in $\mathrm{MZ}$ and DZ twins and at their association with differences in cardiovascular and metabolic parameters. Twin studies can resolve whether these associations are causal, or due to shared genetic factors. For blood pressure, it turned out that the association between low birth weight and high blood pressure in later life ismediated by common gene ${ }^{37}$.

In a moregeneral version of this design, MZ twins, only one of whom has a disease, are used in geneexpression studies to distinguish between genes that are related to the causes of the disease and genes that are expressed as a consequence of the disease. Alternatively, such differential expression, congruent with disease discordance, might indicate causal genes that are

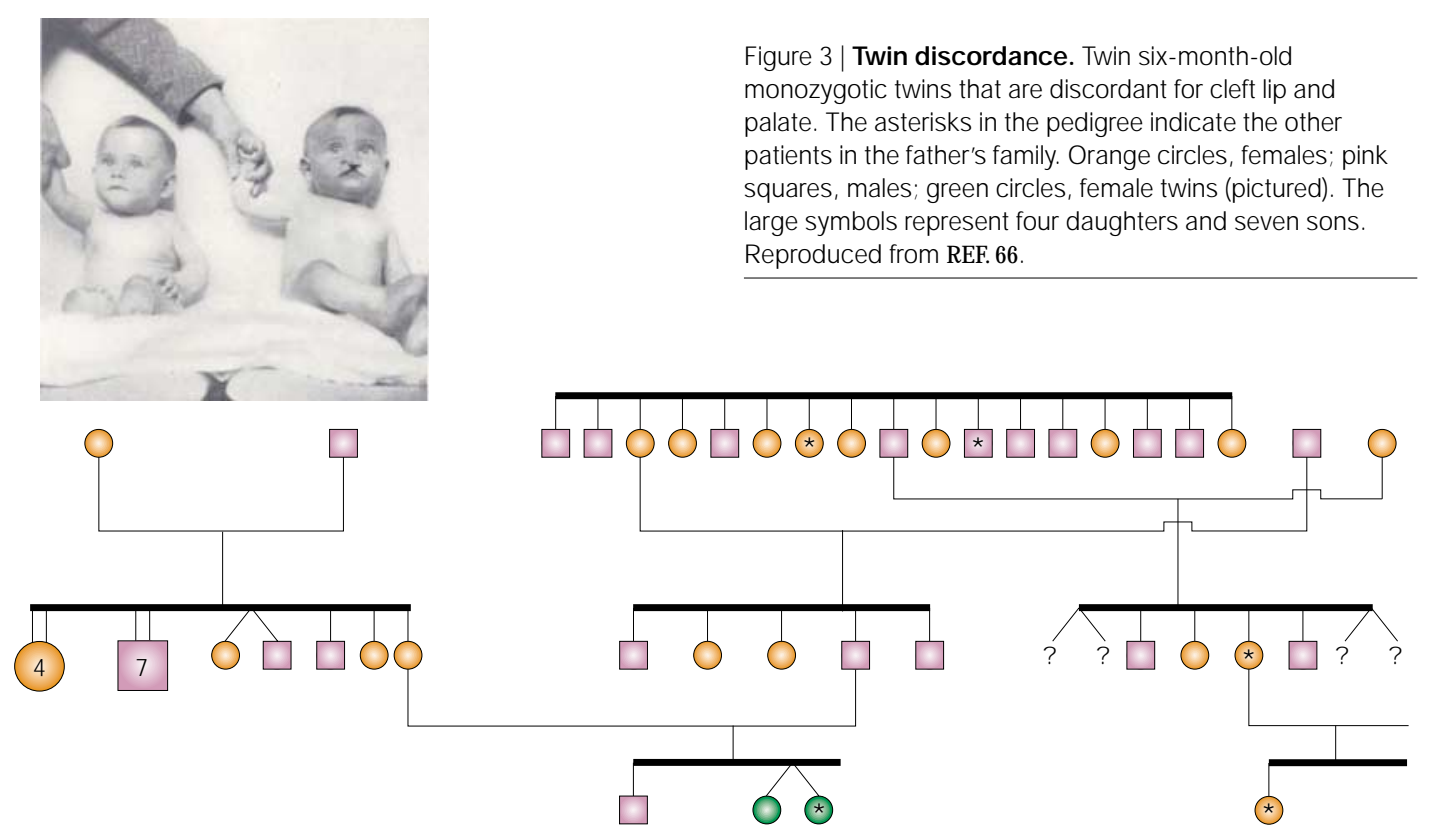

differentially activated by epigenetic factors ${ }^{38}$. Conversely, the detection of somatic mutation of the samegenein tumours from MZ twins, both of whom have the tumour, might bea powerful way to detect predisposition genes ${ }^{39,40}$

\section{The use of twins in molecular-genetic studies} The concordance between M Z twins sets the upper limit on predictions of individual risk that can be made on the basis of the human genome sequence. Discordant M Z schizophrenic twins, for example, show that disease outcome can be different for two individuals with an identical genetic make-up. The same is also illustrated by M Z twins with cleft lip and palate (FIG. 3). M Z-twin concordance therefore gives important information about disease PENETRANCE and, if MZ twins are genotyped at candidate loci, they provideinformation about locusspecific penetrances. For quantitative traits, an association between a particular genotype and MZ-trait differences might not only reveal the relationship between the gene and the trait, but also indicate that the genemight bea 'variability', as opposed to a'level', gene. Theidea of variability and level genes was introduced by Berg et al. ${ }^{41}$ who wereinspired by the study of intra-pair variancefor cholesterol in $\mathrm{MZ}$ twins of $\mathrm{M}$ - or $\mathrm{M}+$ blood group ${ }^{42}$. Level genes are considered to affect themean expression of a trait, or prevalencein the case of a disease, and arethe usual target of association studies. By contrast, variability genes need not influencetrait levels; instead, they determinethe extent of theinfluencethat the environment has on theintra-individual variability.

In rare cases, $M Z$ twins might inherit nearly, but not completely, identical genotypes. Skewed X-inactivation chondria, somatic mutations and rearrangements of epigenetic signals during gametogenesis might all account for differences between $M Z$ pairs of twins ${ }^{34,38}$. Such MZ twins might be extremely informative in

Figure 3 | Twin discordance. Twin six-month-old patients in the father's family. Orange circles, females; pink squares, males; green circles, female twins (pictured). The large symbols represent four daughters and seven sons. Reproduced from REF. 66 in female M Z twins, asymmetric transmission of mito- 
molecular-genetic studies, as was recently shown. A pair of $\mathrm{MZ}$ twins that were discordant for Van der Woude syndrome(VWS) helped to identify theinterferon regulatory factor 6 gene (IRF6) as thelocus that is responsible for the syndrome. Subsequently, the samemutation was identified in 45 unrelated affected families ${ }^{43}$.

Twins might also offer specific advantages in genome-widegenotyping, such as linkageor association studies, to map QTL. DZ twins are siblings of the same age, so for traits that change with age, this fact will decrease variance and therefore increase the power for linkagestudies. Twinsarealso matched for a broad range of pre and postnatal factors and are more likely than other siblings to havethesame father. The value of combining linkage analyses for $M$ endelian traits in large pedigrees with twin-based QTL linkage was shown in mapping a cholesterol-lowering gene, known as CLG (or M M P1) ${ }^{44}$. The mapping of this geneto chromosome 13 was based initially on a singleArab pedigree. Thesubsequent linkage study in German DZ twins not only confirmed the locus, but al so added information on the relevance of the as-yet-unknown geneby showing its influenceon lipid levelsin the general population.

of course, MZ-twin data do not contribute towards detecting linkage, as M Z twins share all their genetic material, being identical by descent. H owever, analysing M Z phenotypic data simultaneously with the linkage data in $D Z$ twins and sibling pairs makes it possible to distinguish between the effects that background genes and a shared family environment have on the amount of familial variance that is not accounted for by the QTL.

Risch and Zhang ${ }^{45}$ have proposed that stringent selection of extreme discordant and concordant (EDAC) pairs might be the only reliable strategy for QTL mapping in humans. Large registers of twins (see next section) contain the phenotypes of thousands, sometimes tens of thousands, of twins and their family members, and are a suitable source of families that are informative for linkage studies. Several such QTLmapping projects arenow under way. For example, the genes that influence neuroticism and depression are sought in selected samples of twins and their siblings ${ }^{46-48}$. DZ twins are used to ensure that extremely discordant pairs arenot selected because of age differences between them. For ordinary sibs, age differences might be responsible for largephenotypic differences.

\section{Twin registers worldwide}

Getting off theground. Many of the current twin registers (TABLES 2,3) are spin-offs from specific research projects, usually in psychology or medicine. For example, the East Flanders Prospective Twin Study, now among the most comprehensive collections of perinatal twin data, started after the observation of lower degrees of intra-uterinehypoxia in second-born twins. TheBerlin Twin Register started as a study on the genetics of blood-pressure regulation during mental stress. Once scientists gain experience with twin research, they usually realize the great potential of such studies that extend beyond theoriginal question and thenecessity to 'nurse' this source of data. Resources allowing, a twin collection develops into a register. To definea register, weneed to take into account thenecessity to maintain and extend theoriginal sample and data collection, the samplesize and range, and the sophistication of the data. For this overview, we havechosen large, population-based registers with up to 150,000 pairs of twins, as well as small, but growing, collections of less than a hundred pairs.

The existing or emerging population-based registers, such as those in Scandinavia, Italy, Korea and Sri Lanka, are of extremevalue for epidemiological research owing to the lack of ascertainment bias. In some countries, the sampling of pairs of twins is based on computerized population registers, either by using direct information on multiple births or by applying complex filters including sharing of date of birth, family name at birth, place of birth or partly sharing identification numbers. Norway, which has one of thelargest twin collections, established a computerized twin register in 1990, but a traditional nationwide archive of birth register was established by the'Act of Castbergian' as early as 1916. In the absence of government address records, substitutes such as drivers licencerecords are being used to trace twins. But unbiased population samples can be obtained using local or regional rather than nationwide approaches, as has been shown in Sri Lanka wherehospital records of themain maternity hospitals were used as a source of information on twins. In all cases, 'real' twins have to be distinguished from a larger subset of 'potential' twins, as sharing the name of their mother and their date of birth might occur by chance ${ }^{49}$. Other twin collections are gathered independently of centralized records and therefore depend more on themotivation of the twins or their parents. Recruiting twins through advertising of twin studies has been used in some cases, as well as through mass-media articles on twins and twin research, in which information on major achievements were combined with continuing studies and contact information. These approaches have been surprisingly effective, and the possible effects of bias in such non-randomly ascertained samples can bedealt with efficiently by statistical methods ${ }^{50,51}$.

$M$ any researchers havestarted to realize the value of large data collections for molecular-genetic studies and have begun to includesiblings, parents and offspring of twins in their research projects.

Runningtheregisters. Recruiting twins is only the first step in running a twin register. There are many processes that are involved in breathing life into such a data collection. Keeping addresses up-to-date, maintaining contact with and motivating twins are continuous tasks. In this respect, twin registers face the same problems as other large epidemiological collections, except that the chances of re-establishing contact are almost doubled owing to the family-based sample and the close relationship of most twins. For all the main registers, rules for starting new data collections have been developed. All the registers included in this overview are open to collaboration, provided that scientific review confirms the merits of a research 
proposal, that there are no ethical concerns and that funding is available. Basic funding is typically provided either nationally by the National Institutes of $\mathrm{H}$ ealth in the United States (or equivalent funding agencies elsewhere), or internationally, such as by the European Community. Specific studies on twins are funded by the same grants as are other medical and psychology studies.
Data collection. Administrators of most registers maintain contact with thetwins and their family members through Web sites (TABLES 2,3), by sen ding out newsletters and through mailed surveys. Even DNA samples have been collected by post - for example, DNA from buccal swabs has been collected in this way ${ }^{52}$. The data collection by mailed questionnaires has led to somevery large data sets. For example, Lakeet al. ${ }^{53}$ analysed data

\begin{tabular}{|c|c|c|c|c|c|}
\hline Twin studies & $\begin{array}{l}\text { URL or contact e-mail } \\
\text { address }\end{array}$ & $\begin{array}{l}\text { Number } \\
\text { of twins }\end{array}$ & Primary interest & $\begin{array}{l}\text { Origin } \\
\text { of twins }\end{array}$ & References \\
\hline $\begin{array}{l}\text { East Flanders Prospective } \\
\text { Twin Survey (EFPTS) }\end{array}$ & c.derom@pi.de & 6,050 & $\begin{array}{l}\text { Epidemiology, placentation*, } \\
\text { congenital anomalies, perinatal } \\
\text { factors and the Barker hypothesis }\end{array}$ & Belgium & 56,67 \\
\hline The Danish Twin Registry & askytthe@health.sdu.dk & 65,000 & $\begin{array}{l}\text { Ageing and age-related health, } \\
\text { metabolic and cardiovascular disease, } \\
\text { and specific diseases }\end{array}$ & Denmark & 56,68 \\
\hline The Finnish Twin Cohort & jaakko.kaprio@helsinki.fi & 15,000 & $\begin{array}{l}\text { Health, personality and substance } \\
\text { abuse }\end{array}$ & Finland & 56,69 \\
\hline $\begin{array}{l}\text { Berlin Twin Register } \\
\text { (HealthTwiSt) }\end{array}$ & http://www.healthtwist.de & $>900$ & $\begin{array}{l}\text { Complex diseases, health-related } \\
\text { QTs and pharmacogenetics }\end{array}$ & Germany & 56,70 \\
\hline $\begin{array}{l}\text { German Observational Study } \\
\text { of Adult Twins (GOSAT) } \\
\text { and the Bielefeld } \\
\text { Longitudinal Study of } \\
\text { Adult Twins (BiLSAT) }\end{array}$ & angleitner@uni-bielefeld.de & 2,509 & $\begin{array}{l}\text { Longitudinal assessment of } \\
\text { temperament and personality; } \\
\text { generalizability of behavioural genetic } \\
\text { findings across methods of personality } \\
\text { assessment }\end{array}$ & Germany & 56,71 \\
\hline Italian Twin Registry & http://www.gemelli.iss.it & 120,000 & $\begin{array}{l}\text { Ageing, dementia, cardiovascular } \\
\text { diseases, MS, celiac disease, diabetes, } \\
\text { asthma, allergies, thyroid diseases } \\
\text { and behavioural disorders }\end{array}$ & Italy & 56 \\
\hline $\begin{array}{l}\text { Register of Italian Twin } \\
\text { Athletes (RITA) }\end{array}$ & casini@iusm.it & 4,719 & $\begin{array}{l}\text { Human biology and development, } \\
\text { sport and high-level performance }\end{array}$ & Italy & 56 \\
\hline $\begin{array}{l}\text { Twin Register of Rome } \\
\text { (TERRY) }\end{array}$ & casini@iusm.it & 13,228 & Lifestyle, development and ageing & Italy & 56 \\
\hline Norway Twin Registries & mina.bergem@psykiatri.uio.no & $>40,000$ & $\begin{array}{l}\text { Mental health, obesity, asthma and } \\
\text { allergies, health behaviours and percept- } \\
\text { ions, perinatal influence on health }\end{array}$ & Norway & 56,72 \\
\hline The NIPH Twin Panel & jennifer.harris@folkehelsa.no & 7,668 & $\begin{array}{l}\text { Physical and mental health, asthma, } \\
\text { allergies, obesity and health-related } \\
\text { behaviours }\end{array}$ & Norway & 56,73 \\
\hline $\begin{array}{l}\text { The Swedish Twin } \\
\text { Registry }\end{array}$ & http://www.mep.ki.se/twin & 57,405 & $\begin{array}{l}\text { Cancer, cardiovascular diseases, } \\
\text { dementia, depression, substance use/ } \\
\text { abuse, cognition, personality, ageing } \\
\text { and common complex diseases }\end{array}$ & Sweden & 56,74 \\
\hline $\begin{array}{l}\text { The Swedish Young Male } \\
\text { Twins Study }\end{array}$ & finn.rasmussen@imm.ki.se & 1,783 & $\begin{array}{l}\text { Risk factors for metabolic and } \\
\text { cardiovascular diseases; obesity } \\
\text { and behavioural risk factors }\end{array}$ & Sweden & 56 \\
\hline $\begin{array}{l}\text { Netherlands Twin Register } \\
\text { (NTR) }\end{array}$ & http://www.psy.vu.nl/ntr & 30,335 & $\begin{array}{l}\text { Development, behaviour and } \\
\text { emotional problems; cognition, } \\
\text { depression, addiction and cardio- } \\
\text { vascular risk factors }\end{array}$ & $\begin{array}{l}\text { The } \\
\text { Netherlands }\end{array}$ & 23,56 \\
\hline $\begin{array}{l}\text { St Thomas' UK Adult Twin } \\
\text { Registry }\end{array}$ & http://www.twin-research.ac.uk & 10,000 & $\begin{array}{l}\text { Cardiovascular, metabolic, musculo- } \\
\text { skeletal, dermatological and } \\
\text { ophthalmological diseases }\end{array}$ & UK & 56,75 \\
\hline $\begin{array}{l}\text { Study of growth before } \\
\text { birth and adult health }\end{array}$ & g.mcneill@abdn.ac.uk & 123 & $\begin{array}{l}\text { Risk factors for coronary heart } \\
\text { disease }\end{array}$ & UK & 56 \\
\hline $\begin{array}{l}\text { Twins' Early Development } \\
\text { Study (TEDS) }\end{array}$ & a.trouton@iop.kcl.ac.uk & 16,810 & $\begin{array}{l}\text { Longitudinal assessment of verbal } \\
\text { and non-verbal cognitive development } \\
\text { and delay; language development and } \\
\text { delay; childhood behaviour problems }\end{array}$ & UK & 56 \\
\hline $\begin{array}{l}\text { Northern Region Multiple } \\
\text { Pregnancy Register }\end{array}$ & christopher.wright@ncl.ac.uk & 1,216 & $\begin{array}{l}\text { Effects of multiple pregnancy, } \\
\text { obstetric and paediatric management, } \\
\text { and outcomes of pregnancy }\end{array}$ & $\begin{array}{l}\text { UK } \\
\text { (North East) }\end{array}$ & 56 \\
\hline
\end{tabular}

*Chorion type. MS, multiple sclerosis; NIPH, National Institute of Public Health; QT, quantitative trait. 
from more than 45,000 twins and their relatives on neuroticism, which is a strong risk factor for the development of depression, and concluded that familial resemblance for this trait has a simple genetic basis. Because of the large data sets that are available, it was possible to reject alternative models for familial resemblance, such as cultural transmission.

Although samplesize is clearly important in genetic epidemiology, there is sometimes a pay-off in the amount of data that can becollected through questionnaires and large-scale survey studies, and the scope or depth of phenotypesthat need to be collected in laboratory settings. To study the genetic basis of disease, intermediate phenotypes often need to be determined in more extensive and costly studies. The selection of subsamples can be based on random selection and also on previous phenotyping from thelarger registers (as, for example, in the Australian (TABLE 3) or Scandinavian (TABLE 2) registers); alternatively, smaller twin cohorts can be collected for specific studies. The Register of Italian Twin Athletes, or the Study of Growth Before Birth and Adult Health (TABLE 2) are good examples of successful in-depth studies on a small scale.

Central ized health databases that exist in somecountries greatly facilitate efficient data collection. Finland and other Scandinavian countries have centralized registers for hospital discharge data and for fully reimbursable medications. This information is accessible with a unique personal identifier that is given to each individual at birth. This al lows record linking for all twins without any self-selection as potential bias. Personal identifiers of twins are used as a query filter for the health databases, and matching records can then be transferred into the twin database. This strategy was successfully used by Lichtenstein et al..$^{54}$ to obtain heritability estimates for 28 anatomically distinct types of cancer. The authors combined data on 44,788 pairs of Swedish, Danish and Finnish twins and found that genetic factors only make a minor contribution to susceptibility to most types of neoplasm. (H owever, Risch ${ }^{55}$ argues that, for some cancers, the data are compatible with a much larger influence of genetic factors.)

Unique features of individual registers. The behavioural measurements collected for twin registers rangefrom questionnaire-based personal ity traits that are catalogued in many registers, to standardized psychiatric interviews obtained by telephone and behavioural responses recorded on video during real-life situations (such as in the Bielefeld twin studies, TABLE 2). In studies of young and adolescent twins, substantial resources are devoted to developmental studies of psychopathology and substance use and abuse. Clinical measurements can be collected and include diagnoses, as well as specific measures such as bone density (as in theSt Thomas twin register in London) and magnetic resonanceimaging scans for cardiac function and morphology (as in the Berlin register) (TABLE 2). M any registers focus on cardiovascular diseaseand on metabolic syndromes and their intermediate phenotypes (for example, the Netherlands Twin Register (TABLE 2) and the'Project
Grow-2-Gether' in New York (TABLE 3)). The determination of various phenotypes across various regions of interest in the same twin cohort greatly adds to the value of the data collection by allowing multivariate study designs. Traits such as eating habits, addiction or coping with stress are related to various health measures, based either on underlying common genetic or environmental influences or on direct effects. Twin methodology is suitable to disentanglethis complex relationship, given that the relevant measures are available.

The value of a twin register is not so much determined by the existing database as by the ability to go back to thetwins to add information about the phenotypes in a hypothesis-driven manner. Any finding leads to new questions, and genetic research is no exception to this rule. Finding a disease-rel evant gene leads to the question of thephysiological pathway in which it acts and the subsequent need for related physiological measures, known as (endo)phenotyping. M ost twin registers operatein a longitudinal way, establishing a continuing relationship with study participants, which allows the researcher to go back to interesting families to collect additional data, including DNA samples for moleculargenetic studies. For several registers, longitudinal data collection - for example, to study the development of childhood psychopathology - is the main focus of the endeavour, and twins are recruited at birth or shortly afterwards. TheEast Flanders Prospective Twin Survey registers twins at birth and is unique in that it determines zygosity and placental information on all twins. Data collected throughout the lifetime of the twins offer unique opportunities, provided we can develop new statistical strategies that takeadvantage of such data.

Therange of phenotypes that are available in the existing registers covers many kinds of behavioural and clinical trait. A more-detailed description of the registers, thesamples of twins and twin family members, and the phenotypic data collection, are availablein a special issue of Twin Research ${ }^{56}$ published in October 2002, which is devoted to twin registers worldwide and from which TABLES 2,3 are abstracted.

\section{Conclusion and prospects}

For multifactorial traits (such as body height and weight, neuroticism and blood lipid levels) and complex diseases (such as obesity, depression and cardiovascular disease), twin studies have shown that genetics contributes significantly to the variation that is seen at the population level. M any of these traits and diseases are now on the increase in large areas of the world and are influenced by risk factors that include diet, smoking and lack of exercise ( see, for example, REF. 57). Although these'lifestyle' risk factors that are important for the devel opment of complex diseases are often considered to be 'environmental', they might themselves be influenced by genes. Twin studies have been useful in assessing the extent to which variation in lifestyle and healthy behaviour might itself beheritable. In fact, recent twin studies provided considerable evidence that 'lifestyle' risk factors aggregate in families owing to shared genes, in 
addition to the shared environment. For example, twin studies have indicated that differences in eating patterns $s^{58}$, alcohol use ${ }^{16}$, smoking initiation and persistence ${ }^{59,60}$, sports participation ${ }^{61}$ and even religious beliefs ${ }^{62,63}$ might all be influenced by genetic variation. Heritability for a particular disease might therefore reflect the direct influence of disease genes, the influence of genes that are responsible for variation in lifestyle factors or the influence of genes that modify the influence of lifestyle on disease risk.
The value of large, unbiased study samples that are needed to verify the role of the genetic variation that underlies common traits is well recognized. As pointed out by Thompson ${ }^{64}$, we havenow moved into an era in which genotyping is relatively cheap and fast, and the main cost of a study of a complex trait involves family data collection and trait phenotyping. This view is reflected in a recent decision by the European Community to fund a large integrated project called GEN OM EUTWIN . Thesix participating twin cohorts

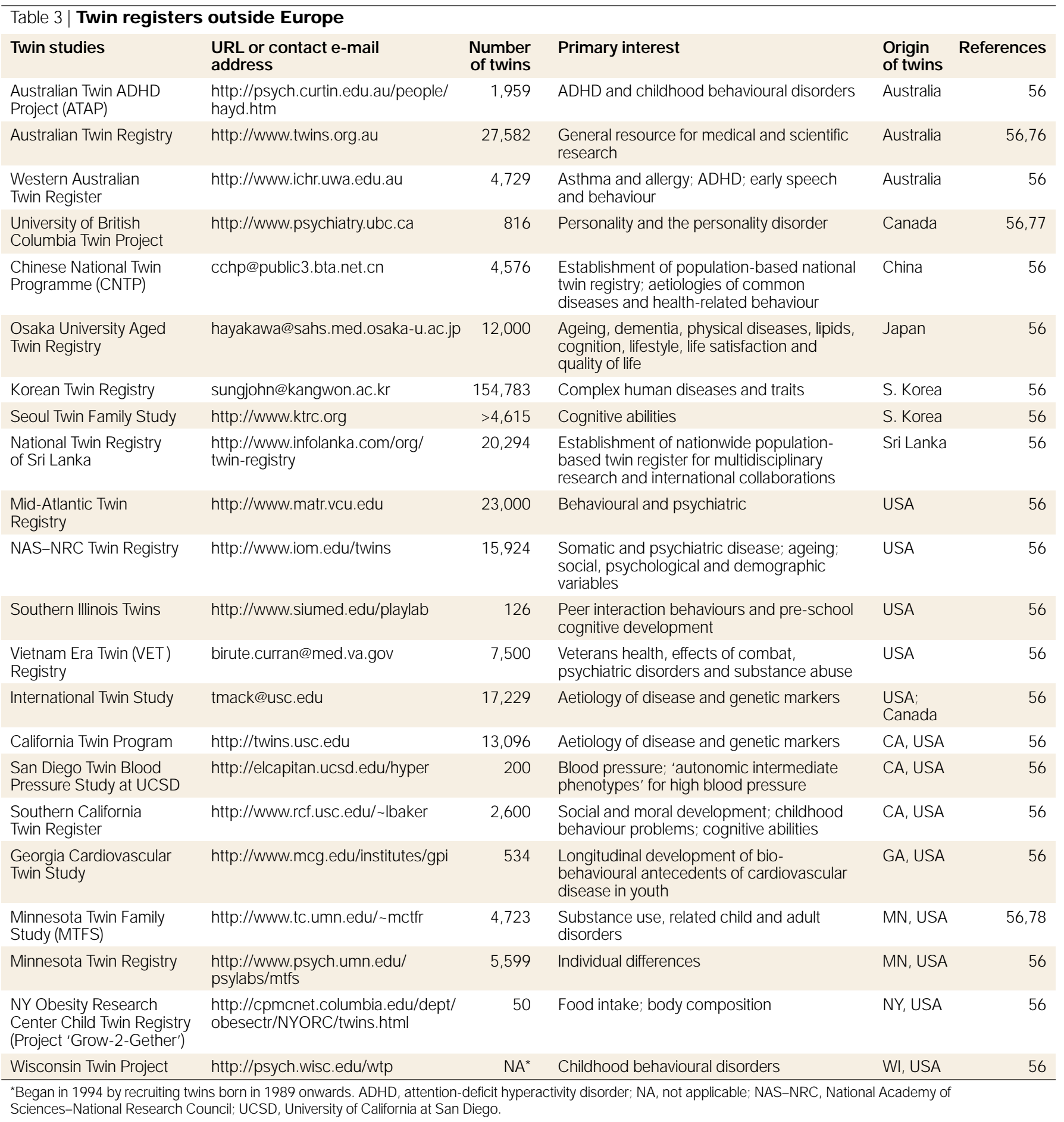


from Scandinavia, The N etherlands and Italy, form an amazing collection of morethan 0.6 million pairs of twins. More than 30,000 D NA samples, accompanied by informed consent for genetic studies of common diseases, have been collected from these populationbased twin cohorts. Combining the data from the main twin registers of Europe will integratethe efforts of the leading genetic and epidemiological researchers in the field of twin research. In this research project, epidemiological and phenotypic data collection will beintegrated, and special emphasis will be placed on quality control of the data to be entered in the databases and on thelevel and reliability of the collected clinical phenotypes, as well as lifestyle factors and specific life events. Initial 'proof-of-principle' genome-wide genotyping efforts will betargeted at 10,000 twins and will look at stature, body mass index, coronary diseaseand migraine.

Twins and their family members are often enthusiastic participants in research studies. Theincreasein the twinning ratethat is now seen in The Netherlands and other countrie ${ }^{65}$ ensures the viability of the application of the classical twin design in genetic epidemiology and in medical, behavioural and psychiatric genetics.
1. Altmuller, J ., Palmer, L. J ., Fischer, G., Scherb, H. \& Wjst, M. Genomewide scans of complex human diseases: true linkage is hard to find. Am. J. Hum. Genet. 69, 936-950 (2001).

2. Ionnidis, J. P. A., Ntzani, E. E., Trikalinos, T. A. \& Contopoulos-loannidis, D. G. Replication validity of genetic association studies. Nature Genet. 29, 306-309 (2001).

3. Korstanje, R. \& Paigen, B. From QTL to gene: the harvest begins. Nature Genet. 31, 235-236 (2002).

4. Sham, P. Shifting paradigms in gene-mapping methodology for complex traits. Pharmacogenomics 2, 195-202 (2001).

5. St Augustine of Hippo. De Civitate Dei (The City of God), New edn (Penguin, 2001)

6. Galton, F. The history of twins as a criterion of the relative powers of nature and nurture. J . R. Anthropol. Inst. Gt Br. Ireland 5, 391-406 (1875).

7. Bulmer, M. G. The Biology of Twinning in Man (Clarendon, Oxford, 1970).

8. Bouchard, T. J \& \& Propping, P. Twins as a Tool of Behavioral Genetics ( ohn Wiley \& Sons, Chichester, UK, 1993).

9. Siemens, H. W. Die Zwillingspathologie: Ihre Bedeutung, ihre Methodik, ihre bisherigen Ergebnisse (Twin Pathology: Its Importance, Its Methodology, Its Previous Results) (Springer, Berlin, 1924).

10. Kendler, K. S., Neale, M. C., Kessler, R. C., Heath, A. C. \& Eaves, L. J . A population-based twin study of major depression in women. The impact of varying definitions of illness. Arch. Gen. Psychiatry 49, 257-266 (1992)

11. Boomsma, D. I., Koopmans, J. R., van Doornen, L.J. P. \& Orlebeke, J . F. Genetic and social influences on starting to smoke: a study of Dutch adolescent twins and their parents. Addiction 89, 219-226 (1994).

12. Plomin, R., DeFries, J . C., Craig, I. W. \& McGuffin, P. Behavioral Genetics in the Postgenomic Era (APA Books, Washington, DC, 2002)

13. Folstein, S. \& Rutter, M. Genetic influences and infantile autism. Nature 265, 726-728 (1977)

14. Faraone, S. V. \& Doyle, A. E. The nature and heritability of attention-deficit/hyperactivity disorder. Child Adolesc. Psychiatry Clin. N. Am. 10, 299-316, viii-ix (2001).

15. Tsuang, M. T., Bar, J. L., Harley, R. M. \& Lyons, M. J . The Hanvard Twin Study of Substance Abuse: what we have learned. Harv. Rev. Psychiatry 9, 267-279 (2001).

16. Heath, A. C. et al. in Behavioral Genetics in the Postgenomic Era (eds Plomin, R., DeFries, J . C., Craig, I. W. \& McGuffin, P.) 309-334 (APA Books, Washington, DC, 2002)

17. Kempthorne, $O \& \&$ Osborne, $R$. H. The interpretation of twin data. Am. J. Hum. Genet. 13, 320-339 (1961).

18. Neale, M. C. \&Cardon, L. R. Methodology for Genetic Studies of Twins and Families, NATO ASI Series D: Behavioural and Social Sciences, Vol. 67 (Kluwer Academic, Behavioural and Social Sciences,

Dordrecht, The Netherlands, 1992). This book describes the theoretical foundations of

twin analysis, as well as its practical application
9. Jöreskog, K. G. \& Sörbom, D. LISREL 8.5, Scientific

19. J öreskog, K. G. \& Sörbom, D. LISREL 8.5, Scientific
Software International, Lincolnwood, llinois, USA <http://sscicentral.com/lisrel/mainlis.htm>(2001)

20. Neale, M. C., Boker, S. M., Xie, G. \& Maes, H. H. $M \mathrm{x}$ : Statistical Modeling 6 th edn, Department of Psychiatry, VCU Box 900126, Richmond, Virginia 23298, USA. Program, documentation and sample scripts available at $<$ http://www. vcuedu/mx> (2002).

A useful source of information on the computer program Mx that is widely used in the twin research program $M x$
community.

21. Eaves, L. J., Last, K. A., Martin, N. G. \& J inks, J. L. A progressive approach to non-additivity and genotype-environmental covariance in the analysis of human differences. Br. J. Math. Statist. Psychol. 30, 1-42 (1997).

22. Heath, A. C., Eaves, L. J \& Martin, N. G. Interaction of marital status and genetic risk for symptoms of depression. Twin Res. 1, 119-122 (1998).

23. Boomsma, D. I., de Geus, E. J., van Baal, G. C. \& Koopmans, J.R. A religious upbringing reduces the influence of genetic factors on disinhibition: evidence for interaction between genotype and environment on personality. Twin Res. 2, 115-125 (1999).

24. Truett, K. R. et al. A model system for analysis of family resemblance in extended kinships of twins. Behav. Genet. 24, 35-49 (1994).

25. Snieder, H., van Doornen, L. J. P. \& Boomsma, D. I. Age-dependency of gene expression for plasma lipids, lipoproteins and apolipoproteins. Am. J. Hum. Genet. 60 638-650 (1997)

26. Nance, W. E. Kramer, A. A., Corey, L. A., Winter, P. M. \& Eaves, L. J. A causal analysis of birth weight in the offspring of monozygotic twins. Am. J . Hum. Genet. 35, 1211-1223 (1983).

27. Kendler, K. S., Neale, M. C., Kessler, R. C., Heath, A. C. \& Eaves, L. J . Major depression and generalized anxiety disorder. Same genes, (partly) different environments? Arch. Gen. Psychiatry 49, 716-722 (1992)

28. Neale, M. C. \& Kendler, K. S. Models of comorbidity for multifactorial disorders. Am. J . Hum. Genet. 57, 935-953 (1995)

29. Roy, M. A., Neale, M. C., Pedersen, N. L., Mathe, A. A. \& Kendler, K. S. A twin study of generalized anxiety disorder and major depression. Psychol. Med. 25, 1037-1049 (1995)

30. Strachan, T. \& Read, A. P. Human Molecular Genetics Ch. 12 (BIOS, Oxford, UK, 1999)

31. Faraone, S. V. \& Biederman, J . Do attention deficit hyperactivity disorder and major depression share familia risk factors? J . Nerv. Ment. Dis. 185, 533-541 (1997).

32. Todd, R. D. et al. Familiality and heritability of subtypes of attention deficit hyperactivity disorder in a population sample of adolescent female twins. Am. J . P sychiatry 158, sample of adolescent

33. Neuman, R. J . et al. Latent class analysis of ADHD and comorbid symptoms in a population sample of adolescent female twins. J. Child Psychol. Psychiatry 42, 933-942 (2001).

34. Martin, N., Boomsma, D. \& Machin, G. A twin-pronged attack on complex traits. Nature Genet. 17, 387-392 (1997).

35. Martin, N. G., Carr, A. B., Oakeshott, J . G. \& Clark, P. Co-twin control studies: vitamin $C$ and the common cold. Prog. Clin. Biol. Res. A 103, 365-373 (1982).

36. Hales, C. N. \& Barker, D. J. The thrifty phenotype hypothesis. Br. Med. Bull. 60, 5-20 (2001).

37. ljzerman, R. G., Stehouwer, C. D. \& Boomsma, D. I Evidence for genetic factors explaining the birth weight-blood pressure relation. Analysis in twins Hypertension 36, 1008-1012 (2000). This paper shows the value of twin studies in distinguishing between genetic and environmental sources for correlation between traits.

38. Petronis, A. Human morbid genetics revisited: relevance of epigenetics. Trends Genet. 17, 142-146 (2001).

39. Forsti, A., J in, Q., Sundqvist, L., Soderberg, M. \& Hemminki, K. Use of monozygotic twins in search fo breast cancer susceptibility loci. Twin Res. 4, 251-259
brintion breast canc.
40. Mack, T. M., Hamilton, A. S., Press, M. F., Diep, A. \& Rappaport, E. B. Heritable breast cancer in twins. Br. J. Cancer 87, 294-300 (2002).

41. Berg, K., Kondo, I., Drayna, D. \& lawn, R. "Variability gene" effect of cholesteryl ester transfer protein (CETP) genes. Clin. Genet. 35, 437-445 (1989).

42. Magnus, P., Berg, K., Borreson, A.-L. \& Nance, W. E. Apparent influence of marker genotypes on variation in serum cholesterol in monozygotic twins. Clin. Genet. 19, 1, 67-70 (1981).

43. Kondo, I. et al. Mutations in IRF6 cause Van der Woude and popliteal pterygium syndromes. Nature Genet. 32, 285-289 (2002)

44. Knoblauch, H. et al. A cholesterol-lowering gene maps to chromosome 13q. Am. J . Hum. Genet. 66, 157-166 (2000) This article combines classical family-based linkage analysis with mapping of a QTL in twins.

45. Risch, N. \& Zhang, H. Extreme discordant sib pairs for mapping quantitative trait loci in humans. Science $\mathbf{2 6 8}$ 1584-1589 (1995)

46. Boomsma, D. I. et al. Netherlands Twin Family Study of Anxious Depression (NETSAD). Twin Res. 3, 323-334 (2000)

47. Kirk, K. Anxiety and depression in twin and sib pairs extremely discordant and concordant for neuroticism: prodromus to a linkage study. Twin Res. 3, 299-309 (2000).

48. Martin, N. et al. A population-based study of personality in 34000 sib-pairs. Twin Res. 3, 310-315 (2000).

49. Goldberg, J. et al. Identification of a cohort of male and female twins aged 65 years or more in the United States. Am. J. Epidemiol. 145, 175-183 (1997).

50. Neale, M. C. \& Eaves, L. J . Estimating and controlling for the effects of volunteer bias with pairs of relatives. Behav. Genet 23, 271-277 (1993).

51. Bechger, T. M., Boomsma, D. I. \& Koning, H. A limited dependent variable model for heritability estimation with nonrandom ascertained samples. Behav. Genet. 32, 145-151 (2002).

52. Meulenbelt I Droog, S., Trommelen, G J ., Boomsma, D. I. \& Slagboom, P. E. High-yield noninvasive human genomic DNA isolation method for genetic studies in geographically dispersed families and populations. Am. J . Hum. Genet. 57, 1252-1254 (1995).

53. Lake, R. I., Eaves, L. J., Maes, H. H., Heath, A. C. \& Martin, N. G. Further evidence against the environmenta transmission of individual differences in neuroticism from a collaborative study of 45,850 twins and relatives on two continents. Behav. Genet. 30, 223-233 (2000).

54. Lichtenstein, P. et al. Environmental and heritable factors in the causation of cancer - analyses of cohorts of twins from Sweden, Denmark, and Finland. N. Engl. . . Med. 343, 78-85 (2000)

55. Risch, $\mathrm{N}$. The genetic epidemiology of cancer: interpreting family and twin studies and their implications for molecular genetic approaches. Cancer Epidemiol. Biomarkers Prev. 10, 733-741 (2001).

56. Twin Research 5 (October) [epub ahead of print] <http://www.australianacademicpress.com.au/Publications/ TR/TR.html> (2002)

Twin Research is the official journal of the International Society for Twin Studies. This issue gives details on most of the existing twin registers.

57. Willett, W. C. Balancing life-style and genomics research for disease prevention. Science 296, 695-698 (2002).

58. Van den Bree, M. B., Eaves, L. J. \& Dwyer, J . T. Genetic and environmental influences on eating patterns of twins aged $\geq 50$ y. Am. J. Clin. Nutr. 70, 456-465 (1999). 
59. Koopmans, J. R., Slutske, W. S., Heath, A. C.. Neale, M. C. \& Boomsma, D. I. The genetics of smoking initiation and quantity smoked in Dutch adolescent and young adult twins. Behav. Genet. 29, 383-393 (1999).

60. Madden, P. A. et al. The genetics of smoking persistence in men and women: a multicultural study. Behav. Genet. 29, 423-431 (1999)

61. Beunen, G. \& Thomis, M. Genetic determinants of sports participation and daily physical activity. Int. J . Obes. Relat. Metab. Disord. 23 (Suppl.3), S55-S63 (1999).

62. Eaves, L. et al. Comparing the biological and cultural inheritance of personality and social attitudes in the inheritance of personality and social attitudes in the
Virginia 30,000 study of twins and their relatives. Twin Virginia 30,000 study of
Res. 2, 62-80 (1999).

63. Bouchard, T. J . J r, McGue, M., Lykken, D. \& Tellegen, A. Intrinsic and extrinsic religiousness: genetic and environmental influences and personality correlates. Twin Res. 2, 88-98 (1999).

64. Thompson, E. A. in Handbook of Statistical Genetics (eds Balding, D. J ., Bishop, M. \& Cannins, C.) 541-563 (J ohn Wiley \& Sons, Chichester, UK, 2001)

65. Derom, R. Orlebeke J Eriksson, A. \& Thiery, M in Multiple Pregnancy. Epidemiology, Gestation \& Perinatal Outcome (eds Keith, L. G., Papiernik, E., Keith, D. M. \& Luke, B.) 145-162 (The Parthenon Publishing Group, New York, 1995)

This book gives a comprehensive overview on al aspects of multiple births.

66. Voute, P. A. De Differentieele Diagnostiek van Tweelingen. Ph.D. thesis, Kemink en Zoon NV, Utrecht
67. Derom, C., Vlietinck, R., Derom, R. \& Van den Berghe, H. Increased monozygotic twinning rate after ovulation induction. Lancet 1, 1236-1238 (1987).

68. Kjeldsen, M. J ., Kyvik, K. O., Christensen, K. \& Friis, M. L. Genetic and environmental factors in epilepsy: a population-based study of 11.900 Danish twin pairs. Epilepsy Res. 44, 167-178 (2001).

69. Cannon, T. D. et al. The inheritance of neuropsychological dysfunction in twins discordant for schizophrenia. Am. J. Hum. Genet. 67, 369-382 (2000)

70. Busjahn, A. et al. QT interval is linked to 2 long-QT syndrome loci in normal subjects. Circulation $\mathbf{9 9}$ syndrome loci in nom

71. Borkenau, P., Riemann, R., Angleitner, A. \& Spinath, F. M. Genetic and environmental influences on observed personality: evidence from the German Observational Study of Adult Twins. J . Pers. Soc. Psychol. 80, 655-668 (2001).

72. Bergem, A. L. M. \& Lannfelt, L. Apolipoprotein E type e4 allele, heritability and age at onset in twins with Alzheimer disease and vascular dementia. Clin. Genet. 52, 408-413 (1997).

73. Harris, J. R., Tambs, K. \& Magnus, P. Sex-specific effects for body mass index in the new Norwegian twin panel. Genet. Epidemiol. 12, 251-265 (1995).

74. Lichtenstein, P. et al. The Swedish Twin Registry: unique resource for clinical, epidemiological and genetic studies.

J. Intern. Med. 252, 184-205 (2002)

75. Spector, T. D. Influence of vitamin D receptor genotype on bone density in postmenopausal women: a British twin study. Br. Med. I 310, 1357-1360 (1995).
76. Hopper, J. L. et al. Genetic, common environment and individual specific components of variance for age- and lean mass-adjusted bone mineral density in 10- to 26-year-old females: a twin study. Am. J. Epidemiol. 147, 17-29 (1998).

77. J ang, K. L. et al. The covariance structure of neuroticism and agreeableness: a twin and molecular genetic analysis of the role of the serotonin transporter gene. J . Pers. Soc. Psychol. 81, 295-304 (2001).

78. McGue, M., lacono, W. G., Legrand, L., Malone, S. \& Elkins, I. Origins and consequences of age at first drink. I. Associations with substance-use disorders, disinhibitory behavior and psychopathology, and P3 amplitude. Alcoholism: Clin. Exp. Res. 25, 1156-1165 (2001).

Acknowledgements

We thank J. F. Orlebeke, A. L. Beem, J. M. Vink, J. J . Hudziak and N. G. Martin for their contributions to this pape

\section{(2) Online links}

\section{DATABASES}

The following terms in this article are linked online to: LocusLink: http://www.ncbi.nlm.nih.gov/LocusLink CLG |IRF6

OMIM: http://www.ncbi.nlm.nih.gov/Omim

attention-deficit hyperactivity disorder | autism | Crohn disease |

Van der Woude syndrome

\section{FURTHER INFORMATION}

International Society of Twin Studies:

http://www.ists.qimr.edu.au

Access to this interactive links box is free online. 